\title{
Effects of Water Volume and Nitrogen Fertilization on Yield and Quality Traits of Air-cured Burley Tobacco (Nicotiana tabacum L.)*
}

\author{
by \\ Salvatore Ascione ${ }^{1}$, Celestino Ruggiero ${ }^{2}$, and Antonietta Napolitano ${ }^{1}$ \\ ${ }^{1}$ Experimental Institute for Tobacco, 84018 Scafati (SA) Italy. \\ ${ }^{2}$ Department of Agricultural Engineering and Agronomy, University of Naples Federico II, 80055 Portici (NA) Italy.
}

\section{SUMMARY}

Based on a two-year field trial in the region of Campania (Southern Italy) the effects of water volume and nitrogen fertilization on the yield and quality of Burley tobacco (Nicotiana tabacum L.) were investigated with reference to the following traits: cured leaf yield, price index, yield value, leaf area, specific leaf weight, burning capacity, color parameters, total alkaloid, nitrate and chloride leaf content. The experimental design was a factorial comparison among three water volumes $(40,80$ and $120 \%$ evapotranspiration (ET)), four nitrogen fertilization levels $(0,80,160$ and 240 $\mathrm{kg} \mathrm{ha}^{-1}$ ) and two genotypes (cv TN86 and the hybrid R7-11). The yield of cured leaves rose with the increase in water and nitrogen availability, albeit at a decreasing rate. With the increase in water volume, the price index, burning capacity, specific leaf weight, total alkaloid and nitrate content decreased, while leaf area and chloride content increased. Up to a rate of $160 \mathrm{~kg} \mathrm{ha}^{-1}$, nitrogen fertilization increased the price index, yield value, burning capacity, leaf area, specific leaf weight, total alkaloid and nitrates, and reduced leaf chloride content especially at $40 \%$ ET water volume. Both, nitrogen fertilization and water volume had little influence on leaf color. The year had considerable effects on yield, leaf area and color parameters, with higher values in the rainier season. In the two years, genotype TN86 showed higher stability for yield and yield value, lower alkaloid and higher nitrate content in the leaf than the R7-11 hybrid. [Beitr. Tabakforsch. Int. 24 (2011) 194-206]

\section{KEY WORDS}

Burley tobacco, N-fertilization, physical and chemical characteristics, price index, water volume, yield.

\section{ZUSAMMENFASSUNG}

Auf der Basis eines zweijährigen Feldversuches in der Region von Campania (Süditalien) wurde der Einfluss der Wassermenge und der Stickstoffdüngung auf die Ausbeute und die Qualität von Burley Tabak (Nicotiana tabacum L.) untersucht. Dabei wurden folgende Eigenschaften betrachtet: der Ertrag des getrockneten Tabakblattes, der Preisindex, die Ertragswerte, die Blattfläche, das spezifische Blattgewicht, die Brennkapazität, die Farbeigenschaften, der absolute Alkaloidgehalt, sowie der Nitrat- und Chloridgehalt der Blätter. Das experimentelle Design war ein faktorieller Vergleich zwischen drei unterschiedlichen Wassermengen (40, 80 und 120\% Evapotranspiration (ET)), vier unterschiedlichen Mengen an Stickstoffdüngung $\left(0,80,160\right.$ und $\left.240 \mathrm{~kg} \mathrm{ha}^{-1}\right)$ und zwei verschiedenen Genotypen (cv TN86 und die Hybride R7-11).

Die Ausbeute an getrockneten Tabakblättern stieg mit höherer Wasser- und Stickstoffverfügbarkeit, wenn auch mit abnehmendem Ausmaß. Mit höheren Wassermengen fielen der Preisindex, die Brennkapazität, das spezifische Blattgewicht, der absolute Gehalt an Alkaloiden und der Nitratgehalt, während die Blattfläche und der Chloridgehalt anstiegen. Die Steigerung des Stickstoffdüngereinsatzes führte bis zu einer Menge von $160 \mathrm{~kg} \mathrm{ha}^{-1}$, speziell bei 40\% ET Wassermengen, zu einem Anstieg beim Preisindex, den Ertragswerten, dem spezifischen Blattgewicht, den absoluten Alkaloid- und Nitratgehalten der Blätter und einem reduzierten Chloridgehalt. Beide Faktoren, die Stickstoffdüngung und die Wassermengen, hatten nur einen geringen Einfluss auf die Blattfarbe. Einen wesentlichen Einfluss auf den Ertrag, die Blattfläche und die Farbeigenschaften zeigte der Gesamtjahresverlauf mit höheren Werten in regnerischen Zeiten. In den zwei Jahren zeigte der Genotyp TN86 eine 
höhere Stabilität bei den Erträgen und Ertragswerten, mit niedrigeren Alkaloid- und höheren Nitratwerten im Blatt als die Hybride R7-11. [Beitr. Tabakforsch. Int. 24 (2011) 194-206]

\section{RESUME}

A partir d'un essai en plein champs mené sur deux ans dans la région de Campanie (dans le Sud de l'Italie), les effets de l'irrigation et de la fertilisation azotée sur le rendement et la qualité du tabac Burley (Nicotiana tabacum L.) ont été étudiées et plus particulièrement le: rendement des feuilles séchées, l'indice des prix, valeur de la récolte, surface foliaire, poids spécifique des feuilles, combustibilité, coloration, alcaloïdes totaux, teneurs en nitrates et en chlorure des feuilles. Le programme expérimental consistait en une comparaison factorielle de trois volumes d'eau (40, 80 et $120 \%$ ET), quatre niveaux de fertilisation azotée $(0$, 80,160 et $240 \mathrm{~kg}$ par ha-1) et deux génotypes (cv TN86 et l'hybride R7-11).

Le rendement des feuilles séchées a augmenté avec l'augmentation de la disponibilité en eau et en azote, bien qu'à des taux décroissants. Avec l'augmentation du volume d'eau, l'indice des prix, la combustibilité, le poids spécifique des feuilles, les teneurs totales en nitrates et en chlorure des feuilles ont diminué, tandis que la surface foliaire et le taux de chlorure diminuaient. Jusqu'à un taux de $160 \mathrm{~kg} \mathrm{ha}^{-1}$, la fertilisation azotée a fait augmenter l'indice des prix, la valeur de rendement, la capacité de combustion, la surface foliaire, le poids spécifique des feuilles, les alcaloïdes et nitrates totaux et a réduit la teneur en chlorure en particulière à $40 \%$ ET de volume d'eau. La fertilisation azotée ainsi que le volume d'eau avaient peu d'influence sur la couleur des feuilles. L'année avait une influence considérable sur le rendement, la surface foliaire et les paramètres de couleur, avec des valeurs supérieures lors de la saison plus pluvieuse. Au cours des deux années, le génotype TN86 a montré une plus grande stabilité de rendement et de valeur de rendement, des teneurs des feuilles en alcaloïdes inférieures et des teneurs en nitrates supérieures à l'hybride R7-11. [Beitr. Tabakforsch. Int. 24 (2011) 194-206]

\section{INTRODUCTION}

Irrigation is the agronomic practice that mostly influences yield of summer crops in the Mediterranean climate. For tobacco, this practice is often not used rationally, thereby resulting in a reduction in product quality. By contrast, when properly used, it increases both yield quantity and quality $(14,49,52,53,54,59,60)$. Not only is water the main component of plant tissues, but it also facilitates mineral absorption and enters all biochemical, physical and cell wall processes that occur in the plant $(24,25,47,48)$. The availability of this factor has a major influence on growth $(16,26,31,55)$ and leaf anatomy $(2,51)$, as well as on the chemical composition of the leaf, that is, on its inherent quality $(21,39,53,61)$.

Among the mineral nutrients, nitrogen is the most important because it promotes plant growth by stimulating cell multiplication. In addition, through the nitrogen compounds in the cured leaf, it influences cured tobacco quality $(6,8,9,34,38,41)$. However, excessive nitrogen application is detrimental to soil and groundwater quality, and often causes water pollution (36).

The response of tobacco to nitrogen fertilization is affected, amongst other things, by environmental conditions, preceding crops, genotypes, and cropping techniques $(4,33,40,58)$. Indeed, while some research has pointed out that nitrogen fertilization higher than $150-200 \mathrm{~kg} \mathrm{ha}^{-1}$ has no effect on tobacco yield $(17,32,44$, $52)$, others show yield increases up to $300(3,12)$ or 400 $\mathrm{kg} \mathrm{ha}^{-1}(35)$, particularly without potassium fertilization (19).

Until recently, it was not unusual for tobacco farmers in southern Italy to overuse water and nitrogen to achieve the maximum vegetal mass. However, EU legislation now enforces the reduction in environmental impact of crop management. Hence our research aimed to evaluate: a) the response of Burley tobacco to nitrogen fertilization rates and water volume in Campania (Southern Italy), in order to obtain the highest yield with a satisfactory cured leaf quality; b) the weight of the experimental factors on the yield and on the main quality parameters; c) the relationships among yield, physical and chemical characteristics of cured leaves.

\section{EXPERIMENTAL}

\section{Site and soil characteristics}

The research was carried out in the years 2001-2002 in Scafati (Southern Italy) at the farm of the Tobacco Experimental Institute, on a volcanic soil, with tobacco as the previous crop. Soil physical and chemical properties are: sand $70.5 \%$, loam $18.6 \%$, clay $10.9 \%$, lime $9.6 \%$, organic matter $1.8 \%$, total nitrogen $0.1 \%$, available $\mathrm{P}_{2} \mathrm{O}_{5}$ 95 ppm (OlSEN method), exchangeable $\mathrm{K}_{2} \mathrm{O} 540$ ppm (ammonium acetate method), field capacity $22.9 \%$ dry weight (D.W.), wilting point $10.9 \%$ D.W., bulk density $1.38 \mathrm{t} \mathrm{m}^{-3}$, electric conductivity $0.22 \mathrm{~d} \mathrm{Sm}^{-1}, \mathrm{pH} 8$.

\section{Field experiment}

The research involved a factorial comparison between three water volumes, four nitrogen fertilization levels and two Burley tobacco genotypes, the cultivar TN86 and the hybrid R7-11 of US origin. Irrigation was applied on a weekly basis, from furrows, with water volumes equal to 40, 80 and $120 \%$ of evapotranspiration (ET). This was estimated by class "A" pan evaporation corrected by applying a pan coefficient of 0.8 and a crop coefficient of 0.4 from transplanting to early growth, of 0.7 from early growth to early bloom and of 1.0 from the latter phase to harvest (18). Nitrogen was applied to the surface, $8(1 / 3)$ and $40(2 / 3)$ days after transplanting, at the rate of 0,80 , 160 and $240 \mathrm{~kg} \mathrm{ha}^{-1}$ as ammonium nitrate. Phosphorus and potassium fertilizers were added during soil preparation, distributing $120 \mathrm{~kg} \mathrm{ha}^{-1}$ of $\mathrm{P}_{2} \mathrm{O}_{5}$ and $80 \mathrm{~kg} \mathrm{ha}^{-1}$ of $\mathrm{K}_{2} \mathrm{O}$ to all the treatments. Transplanting was done on May 4 in 2001 and May 16 in 2002 on rows spaced 0.90 m apart, 


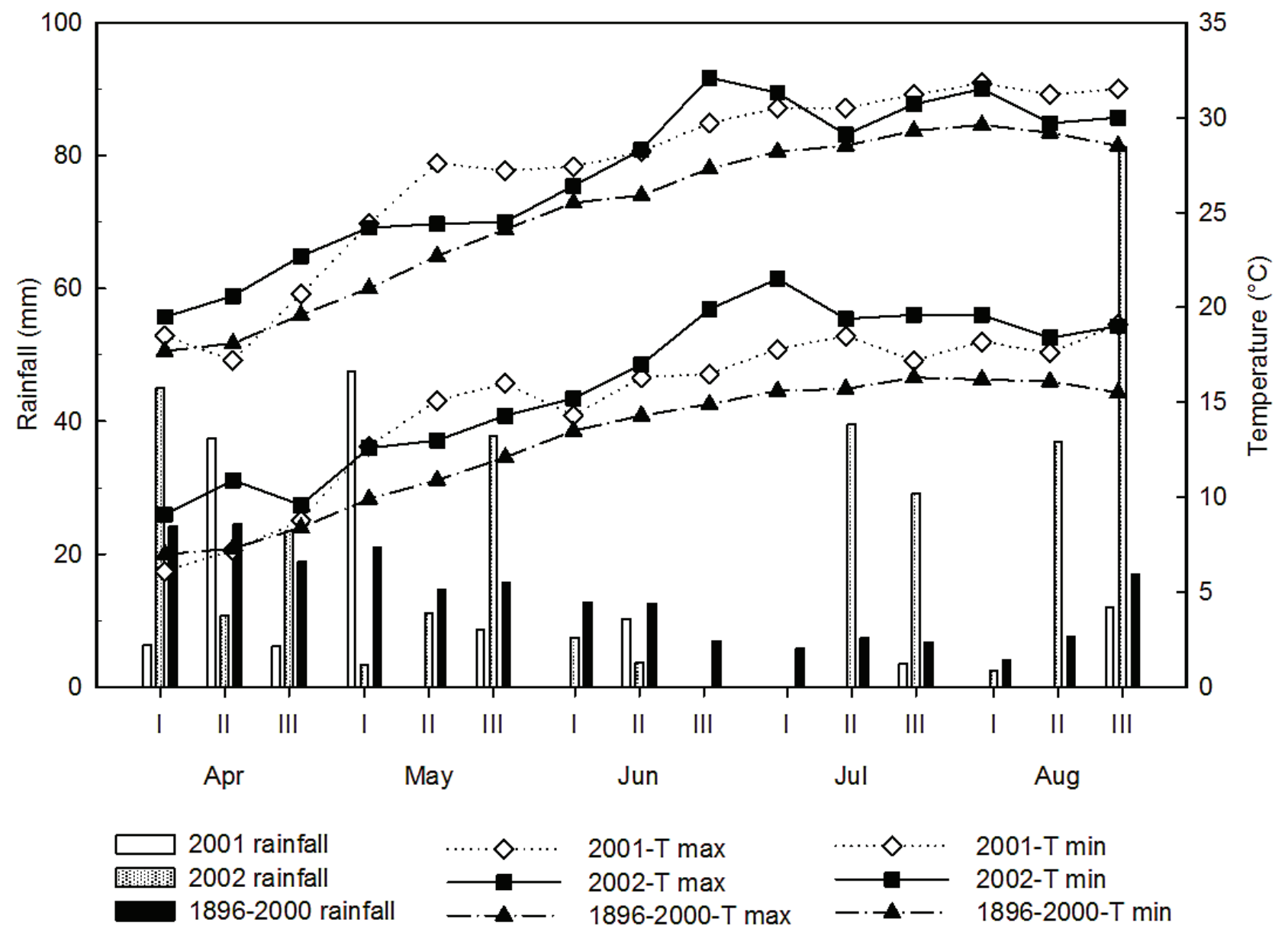

Figure 1. Decadal values of rainfall, mean of maximum (T. max.) and minimum (T. min.) air temperatures registered during the crop growth period and the long-term average 1896-2000.

with plants arranged every $0.35 \mathrm{~m}$ on the row. All cultural practices followed were conventional methods for Burley tobacco production in the zone. Parasite control was carried out as required throughout the crop cycle until flowering. Soil water status was gravimetrically measured every week in $0.30 \mathrm{~m}$ layers, from 0 to $0.90 \mathrm{~m}$, by taking core samples between the rows. The irrigation water had the following mean features: $\mathrm{pH} 6.5$, electric conductivity $2.26 \mathrm{dS} \mathrm{m}^{-1}$, hardness $104.5^{\circ} \mathrm{F}$, chloride $116 \mathrm{mg} \mathrm{L}^{-1}, \mathrm{HCO}_{3}^{-} 1305 \mathrm{mg} \mathrm{L}^{-1}$. At blooming (when $60 \%$ of total plants were between floral bud emergence and full flowering) the plants were topped with 22-24 leaves (the last leaf was longer than $0.30 \mathrm{~m}$ ) and 20 days later they were harvested and subjected to air curing in an appropriate room. Sucker control was done manually at weekly intervals after topping. The harvest was carried out on August 6 in 2001 and August 26 in 2002. The curing time, in both years, was 50 days. The cured leaf yield was evaluated on samples of 80 plants for every elementary plot at $19 \%$ water content.

\section{Technological evaluations}

Following curing, on all sample plants the leaves were stripped and grouped according to their position on the stalk into bottom leaves, middle and upper leaves, and were visually graded in merit classes A, B, C and not classified, for each position, according to physical appearance such as leaf size, color, texture and integrity. The results of this evaluation were expressed as the price index, $\mathrm{PI}=\mathrm{A}+0.65 \mathrm{~B}+0.35 \mathrm{C}(12)$. The index of yield value was calculated by multiplying the price index by the cured leaf yield.

\section{Physical and chemical measurements}

Color parameters, leaf size and specific leaf weight were determined on a random sample of 30 cured leaves according to stalk position and treatment. Burning capacity was evaluated on a sample of 15 leaves, after drying at $50{ }^{\circ} \mathrm{C}$, by measuring the burning time at three positions on the leaf (nearest, halfway and distal). On an analogous sample the total alkaloid, nitrate and chloride concentration were evaluated following NELSON (46). For color a Minolta Chroma Meter CR-210 colorimeter was used to determine, on the median part of each leaf sample, parameters $\mathrm{L}^{*}$ (brightness), $\mathrm{C}^{*}$ (chroma) and $\mathrm{H}^{*}$ (hue). The instrument was set at $6774{ }^{\circ} \mathrm{K}$ (lamp temperature) corresponding to cloudy sky-northern conditions often encountered in the grading warehouse (11), and calibrated with color coordinates of $\mathrm{L}^{*}=97.83, \mathrm{C}^{*}=2.28$, 
$\mathrm{H}^{*}=101.8$. The total color difference was estimated according to the relationship

$$
\Delta \mathrm{e}=\left(\left(\Delta \mathrm{L}^{*}\right)^{2}+\left(\Delta \mathrm{C}^{*}\right)^{2}+\left(\Delta \mathrm{H}^{*}\right)^{2}\right)^{0.5}
$$

Specific leaf weight (SLW) was evaluated by measuring the leaf area (LA) with a Li-3100 area meter and weighing the lamina after drying at $70{ }^{\circ} \mathrm{C}$.

\section{Experimental design and statistical analysis}

A split-plot experimental design was adopted with three replications in a randomized block, with water volume as the main factor, fertilization level as sub-factor and cultivar as sub-sub-factor $\left(57 \mathrm{~m}^{2}\right)$. In the second year the treatments were replicated on the same plots. All the parameters were subjected to analysis of variance (ANOVA) after the homogeneity of variance test for the two years. Differences between the means were evaluated with the least significant difference (LSD) test. Additionally we calculated the multiple linear regressions between the crop parameters and the agronomic factors. At the same time, relationships between physical and chemical parameters were also calculated.

\section{RESULTS}

\section{Weather pattern}

Mean minimum and maximum ten-day temperatures from May to August for the two years were higher than the corresponding historical means recorded at Scafati from 1896-2000 (Figure 1). As regards the two years in question, in 2001 minimum ten-day temperatures were higher during May and lower from June to August, while maximum temperatures were always higher, except for the $3^{\text {rd }}$ decade of June and the $1^{\text {st }}$ of July. Rainfall (Figure 1) was lower $(70 \mathrm{~mm})$ in 2001 than in $2002(171 \mathrm{~mm})$, while the corresponding historical mean from 1896-2000 was $115 \mathrm{~mm}$ (5). During the first year precipitation chiefly occurred in the $1^{\text {st }}$ decade of May, while in 2002 major rainfall was recorded in the $3^{\text {rd }}$ decade of May, the $2^{\text {nd }}$ and $3^{\text {rd }}$ of July and in the $2^{\text {nd }}$ decade of August, with 23 rainy days (rainfall $>1 \mathrm{~mm}$ ). Class "A" pan evaporation (Figure 2a) was always higher in 2001 than in 2002, with the exception of the $3^{\text {rd }}$ decade of June and the $1^{\text {st }}$ of July. Compared to the mean for the period 1980-2000 it was lower only in the $3^{\text {rd }}$ decade of July in 2001 and from the $2^{\text {nd }}$ decade of July until harvest in 2002. Sunshine duration (Figure 2b) and total global radiation (Figure 2c) were lower in 2002 than in 2001, chiefly during the $1^{\text {st }}$ decade of June and after the $2^{\text {nd }}$ decade of July until harvest.

\section{Crop water availability}

Crop water availability was 203, 287 and $401 \mathrm{~mm}$ in 2001 and 305,366 and $418 \mathrm{~mm}$ in 2002, respectively for the three water treatments (40, 80 and $120 \%$ ET). These values were calculated as the sum of irrigation volume supplied, water extracted from the soil (calculated by the means of hydrological balance) and rainfall.

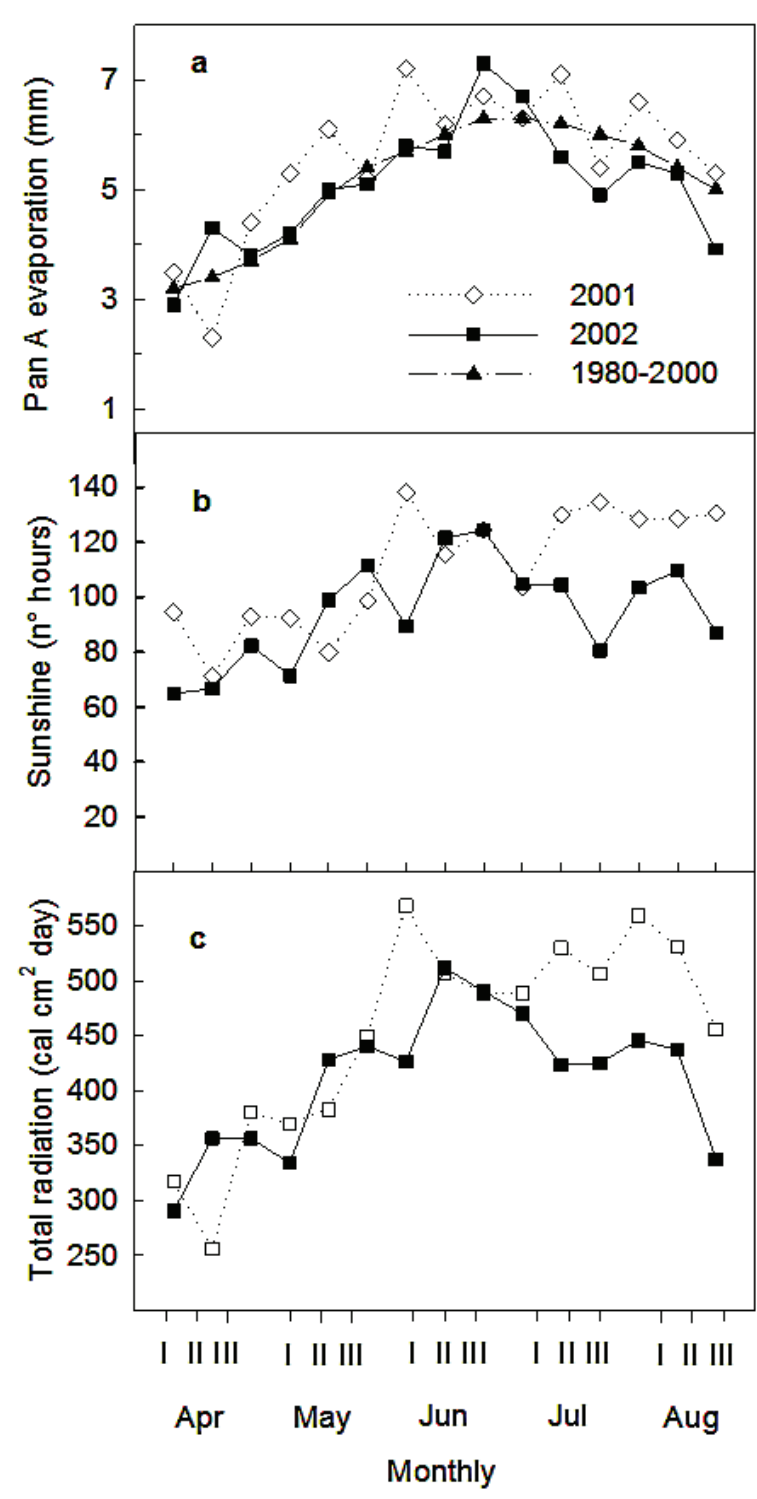

Figure 2. Ten days mean values Class "A" pan evaporation registered during the experimental period and long-term average 1980-2000 (a); ten days sunshine values (b), and ten days mean values of total radiation registered during the crop growth period (c).

\section{Cured leaf yield}

The yield of cured leaves rose with increased $\mathrm{N}$ availability, but at decreasing rates with higher concentrations. The same results were observed with water availability (Figure 3). Nitrogen and water showed interaction effects at the higher levels. With the $120 \%$ ET volume and with 160 and $240 \mathrm{~kg} \mathrm{ha}^{-1}$ of $\mathrm{N}$ the yield increase was higher than that observed with $40 \% \mathrm{ET}$, but statistically not different from $80 \%$ ET. The yield was higher in the second year and especially with the hybrid R7-11, which on average yielded less than cv TN86. N fertilization always increased the price index up to $160 \mathrm{~kg} \mathrm{ha}^{-1}$, while the increase in water volume reduced this parameter, especially in the plot without nitrogen fertilization (Figure 3). The genotypes responded differently in the two years; TN86 showed a higher price index than the hybrid R7-11 with all the nitrogen 


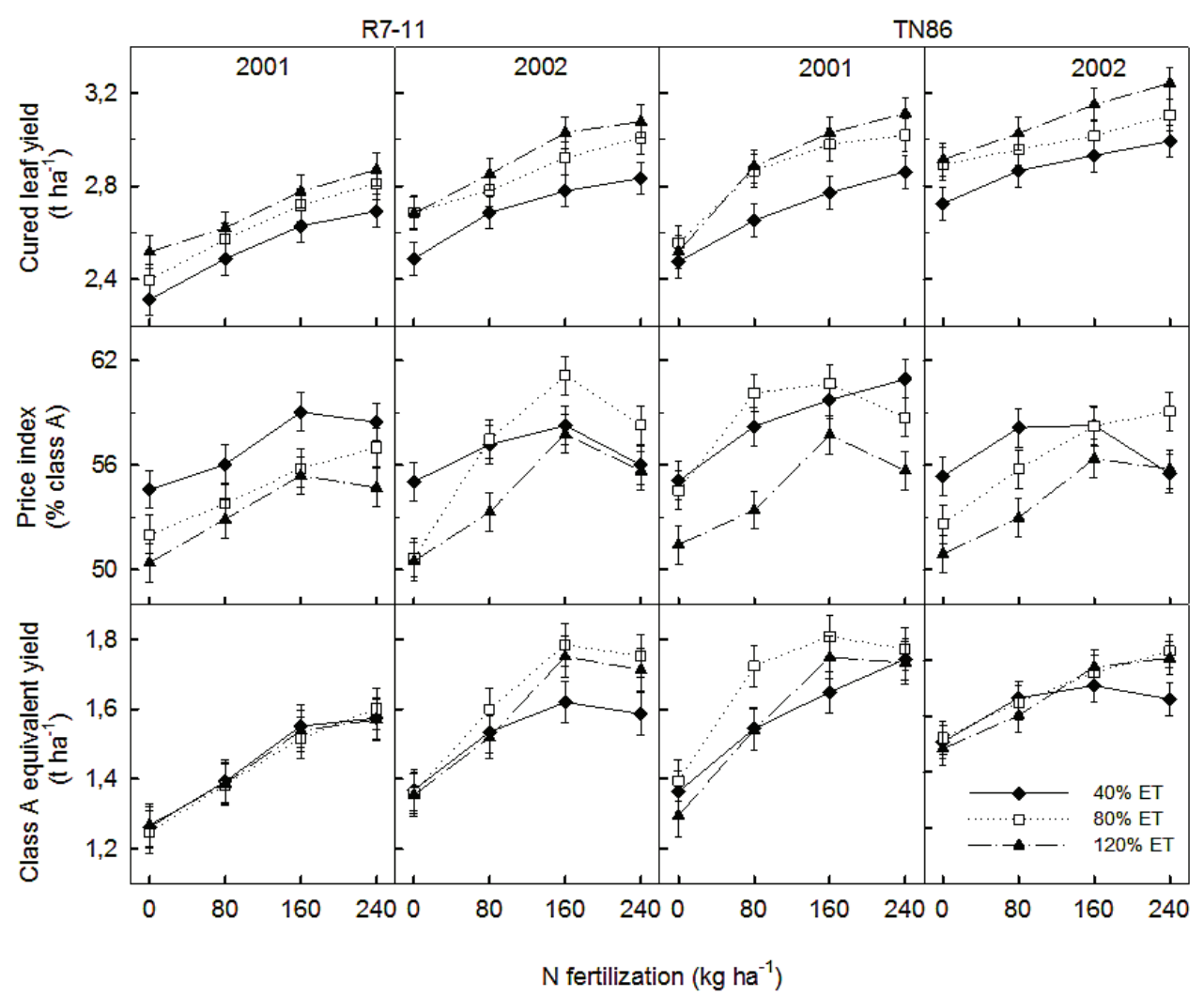

Figure 3. Influence of $\mathbf{N}$ fertilization, irrigation (\% ET), cultivar (R7-11, TN86) and year on cured leaf yield (up), price index of cured leaf yield (centre), and on class A equivalent yield (down). Bars show 95\% pointwise confidence intervals.

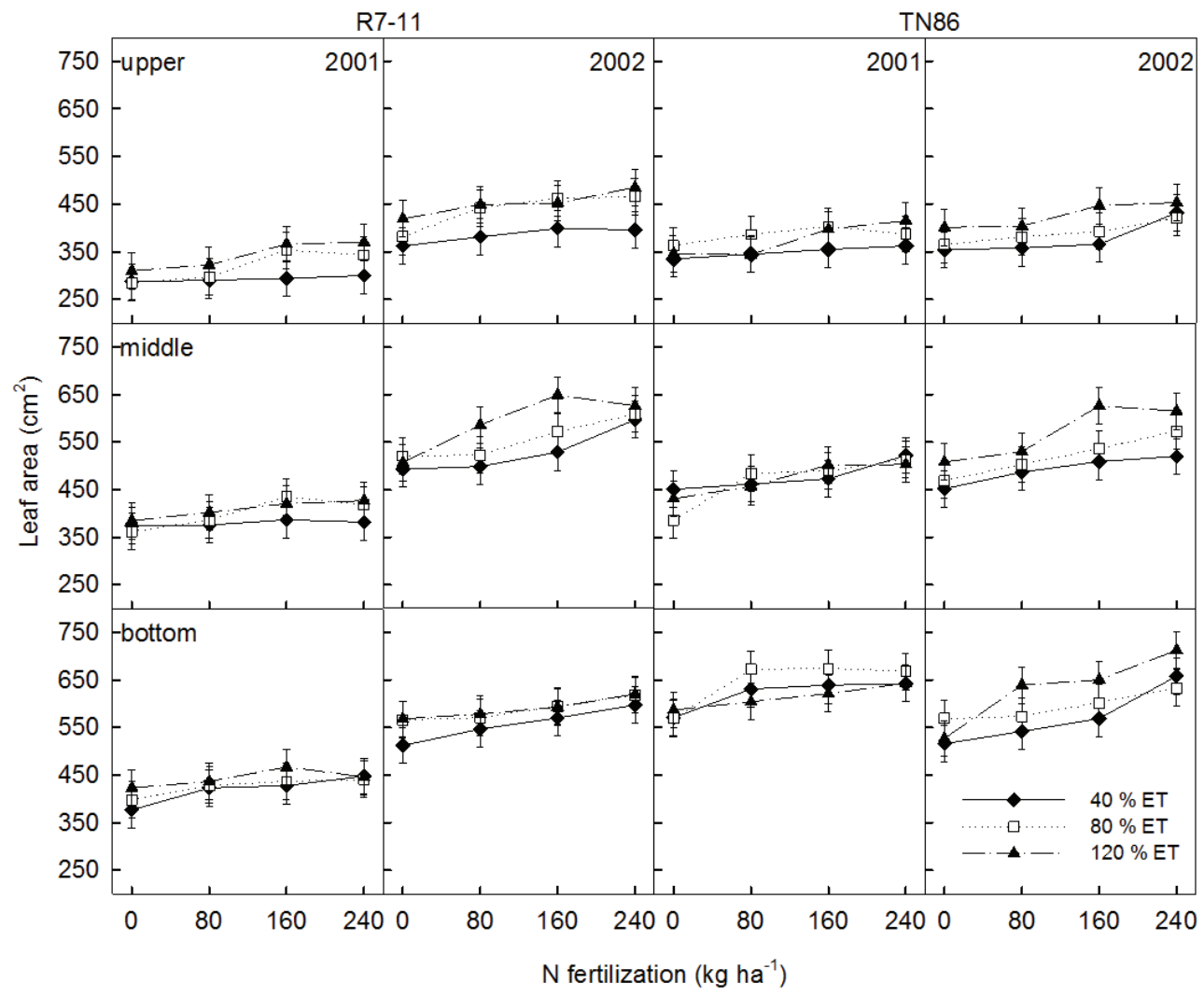

Figure 4. Influence of $\mathbf{N}$ fertilization, irrigation (\% ET), cultivar (R7-11, TN86), year and leaf stalk position on leaf area. Bars show $95 \%$ pointwise confidence intervals. 


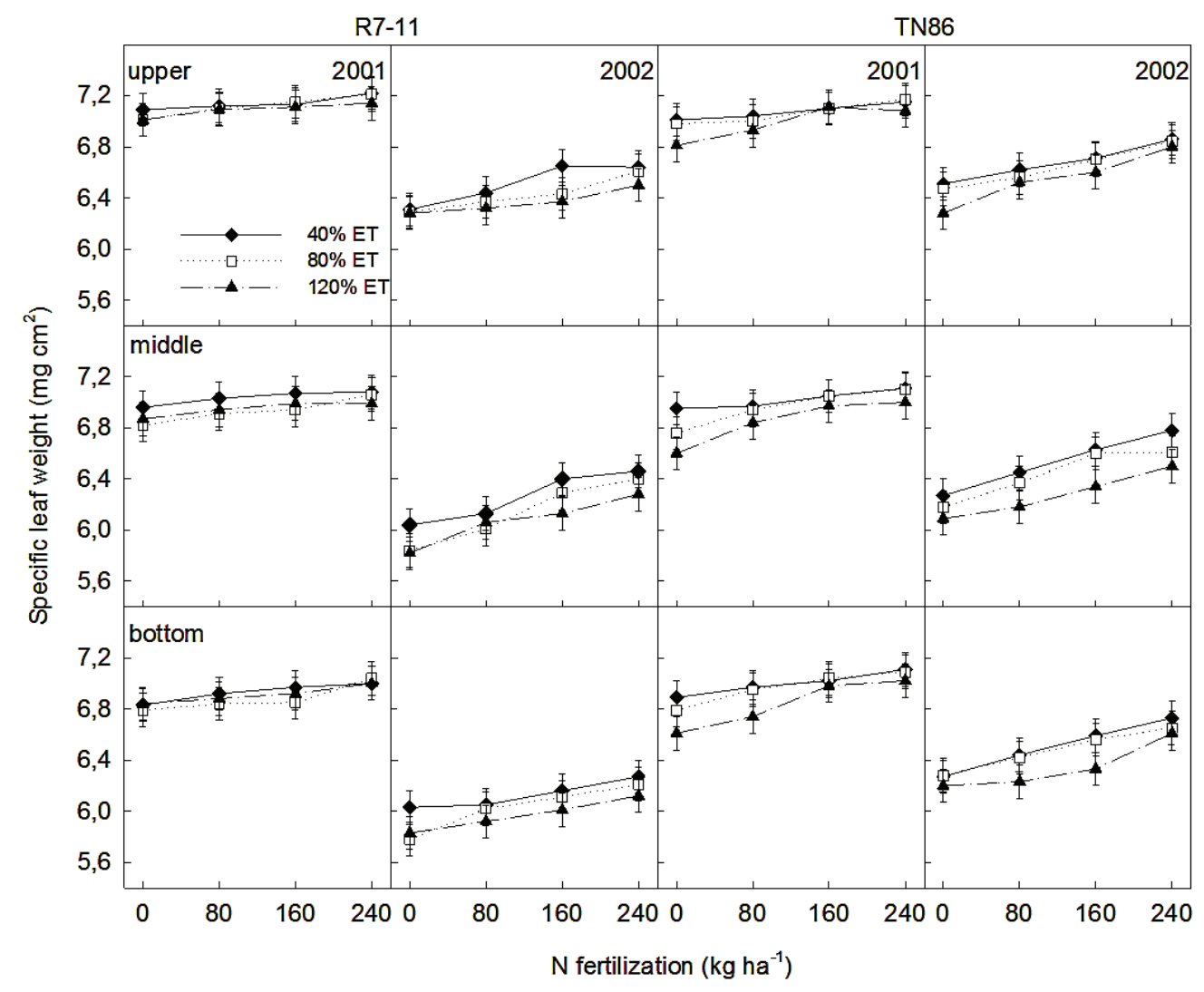

Figure 5. Influence of $\mathbf{N}$ fertilization, irrigation (\% ET), cultivar (R7-11, TN86), year and leaf stalk position on specific leaf weight. Bars show $95 \%$ pointwise confidence intervals.

fertilization levels and water volume in the first year, but showed lower values with 80 and $160 \mathrm{~kg} \mathrm{ha}^{-1}$ of $\mathrm{N}$ with $80 \%$ ET in the second year. According to the response of yield and price index to the factors under observation, the class $\mathrm{A}$ equivalent yield rose with increasing water volumes and $\mathrm{N}$ fertilization, but only up to $80 \%$ ET and $\mathrm{N} 160 \mathrm{~kg} \mathrm{ha}^{-1}$ (Figure 3). However, in the first year the increase in water volume failed to raise the yield value of hybrid R7-11, while with TN86 the higher yield value was achieved with $80 \%$ ET; in the second year the two genotypes showed the same behaviour as the water volume increased.

\section{Physical characteristics of cured leaves}

Leaf area (LA) increased substantially with increasing nitrogen and water availability, being larger in the second year, for TN86, and for bottom leaves (Figure 4). In the first year, the effects of agronomic factors were weak on this parameter, for both genotypes; in the second year, the influence of water volume and $\mathrm{N}$ fertilization was higher on middle and upper leaves for R7-11 and on bottom and middle leaves for TN86.

Specific leaf weight (SLW) increased with $\mathrm{N}$ fertilization and decreased with water volume for both genotypes in the second year, while in the first year it remained unchanged for R7-11 (Figure 5). It was higher in the first year and increased from the bottom to the upper leaf stalk position. The values of leaf chromaticity parameters $\mathrm{L}^{*}, \mathrm{C}^{*}$ and $\mathrm{H}^{*}$ (Table 1) decreased from the bottom to the top stalk position and were higher in the second year. Parameter $\mathrm{C}^{*}$ decreased and $\mathrm{H}^{*}$ increased with the increase in water volume, while
$\mathrm{H}^{*}$ values decreased with $\mathrm{N}$ availability up to $160 \mathrm{~kg} \mathrm{ha}^{-1}$; nitrogen fertilization and water volume did not influence parameter $\mathrm{L}^{*}$. With the cv TN86 higher values were observed for $\mathrm{L}^{*}$ and lower for $\mathrm{C}^{*}$ and $\mathrm{H}^{*}$. However, in the second year the hybrid R7-11 showed, for all stalk positions, higher values of color parameters than those of cv TN86 (data not reported). Total leaf color differences $(\Delta \mathrm{e})$ were higher between years and leaf stalk position. Nitrogen fertilization, water volume and genotype showed small variations in this parameter.

Burning capacity decreased as water volume increased, weakly increased along with $\mathrm{N}$ fertilization, and decreased in relation to leaf stalk position, from bottom to top (Figure 6). The effects of water volume and fertilization level on this parameter were higher for the lower than the upper leaves. Both genotype and year had slight effects on this parameter.

\section{Chemical composition of leaves}

The total alkaloid content decreased as water volume increased, and increased as $\mathrm{N}$ fertilization increased, being higher with the hybrid R7-11, and in the top leaves (Figure 7). The effects of $\mathrm{N}$ fertilization and water volume on this parameter were lower for the bottom and higher for the top leaves. In 2001 the effects of water volume were higher than in 2002, while those of $\mathrm{N}$ fertilization were higher in 2002.

Effects of $\mathrm{N}$ fertilization and water volume on leaf nitrate content were similar to that observed on alkaloid (Figure 8). The nitrate content decreased with stalk 
Table 1. Effects of experimental factors, and leaf stalk position on brightness $\left(L^{*}\right)$, chroma $\left(C^{*}\right)$ and hue $\left(H^{*}\right)$ chromatic parameters, and total color difference for air-cured tobacco leaves.

\begin{tabular}{|c|c|c|c|c|c|}
\hline \multirow{2}{*}{$\begin{array}{l}\text { Source of } \\
\text { variation }\end{array}$} & \multicolumn{3}{|c|}{$\begin{array}{l}\text { Leaf color } \\
\text { parameter }\end{array}$} & \multirow[t]{2}{*}{ Contrasts } & \multirow{2}{*}{$\begin{array}{c}\text { Color } \\
\text { difference }\end{array}$} \\
\hline & $\mathrm{L}^{*}$ & $\mathrm{C}^{*}$ & $\mathrm{H}^{*}$ & & \\
\hline \multicolumn{6}{|l|}{ Year } \\
\hline 2001 & 42.8 & 25.2 & 66.9 & $\Delta \varepsilon 2001$ & 5.41 \\
\hline 2002 & 47.1 & 27.8 & 68.9 & vs & \\
\hline LSD 0.05 & 2.7 & 2.3 & 1.5 & 2002 & \\
\hline \multicolumn{6}{|c|}{ Water vol. $(\% E T)$} \\
\hline 40 & 44.9 & 27.1 & 67.6 & $\Delta \varepsilon 40$ vs 80 & 0.81 \\
\hline 80 & 45.0 & 26.4 & 68.0 & $\Delta \varepsilon 40$ vs 120 & 1.14 \\
\hline 120 & 45.1 & 26.1 & 68.1 & $\Delta \varepsilon 80$ vs 120 & 0.33 \\
\hline LSD 0.05 & n.s. & 0.5 & 0.4 & & \\
\hline \multicolumn{6}{|c|}{ N-rate $\left(k h a^{-1}\right)$} \\
\hline 0 & 45.2 & 26.3 & 68.6 & $\Delta \varepsilon \mathrm{N}_{0}$ vs $\mathrm{N}_{80}$ & 0.72 \\
\hline 80 & 45.2 & 26.7 & 68.0 & $\Delta \varepsilon N_{0}$ vs $N_{160}$ & 1.12 \\
\hline 160 & 44.7 & 26.4 & 67.6 & $\Delta \varepsilon N_{0}$ vs $N_{240}$ & 1.30 \\
\hline \multirow[t]{3}{*}{240} & 44.8 & 26.6 & 67.4 & $\Delta \varepsilon \mathrm{N}_{80}$ vs $\mathrm{N}_{160}$ & 0.71 \\
\hline & & & & $\Delta \varepsilon \mathrm{N}_{80}$ vs $\mathrm{N}_{240}$ & 0.73 \\
\hline & & & & $\Delta \varepsilon \mathrm{N}_{160}$ vs $\mathrm{N}_{240}$ & 0.30 \\
\hline LSD 0.05 & n.s. & n.s. & 0.4 & & \\
\hline \multicolumn{6}{|l|}{ Genotype } \\
\hline $\mathrm{R} 7-11$ & 44.4 & 26.7 & 68.2 & $\Delta \varepsilon R 7-11$ & 1.32 \\
\hline TN 86 & 45.5 & 26.3 & 67.6 & vs & \\
\hline LSD 0.05 & 0.3 & 0.2 & 0.2 & TN86 & \\
\hline \multicolumn{6}{|c|}{ Leaf stalk position ${ }^{a}$} \\
\hline Bottom & 50.3 & 27.9 & 72.2 & $\Delta \varepsilon$ bot.l. vs mid.I. & 3.63 \\
\hline Middle & 47.5 & 28.1 & 69.9 & $\Delta \varepsilon$ bot.l. vs up.l. & 12.13 \\
\hline Upper & 41.1 & 25.1 & 64.8 & $\Delta \varepsilon$ mid.I. vs up.l. & 8.72 \\
\hline LSD 0.05 & 0.2 & 0.1 & 0.2 & & \\
\hline
\end{tabular}

${ }^{a}$ Bot. I.= bottom leaves; mid. I. = middle leaves; up. I.= upper leaves

$\Delta \varepsilon=\left(\left(\Delta \mathrm{L}^{*}\right)^{2}+\left(\Delta \mathrm{C}^{*}\right)^{2}+\left(\Delta \mathrm{H}^{*}\right)^{2}\right)^{0.5}$

position from bottom to top; it was lower in 2002 than 2001 and, on average, higher with the cv TN86, particularly in the drought year.

The chloride content increased with water volume and decreased with $\mathrm{N}$ fertilization, was higher in the top leaves, and in 2001, and, on average, was similar for the two genotypes (Figure 9). Overall, the minimum chloride content was observed with the bottom leaves of $40 \%$ ET and $\mathrm{N} 240$, the maximum in the top leaves with $120 \%$ ET and N0.

\section{Relations between factors and parameters examined}

The multiple regression equations (Table 2) among the agronomic factors under observation and the crop parameters allow some general remarks to be made:

- Year and genotype affected all the parameters except price index and alkaloid content for the year, burning capacity and chloride content for genotype.

- Water volume and nitrogen fertilization positively influenced yield, leaf area, leaf dry weight, unlike other parameters: on price index, specific leaf weight, burning capacity, total alkaloid and nitrate content, water volume had a negative effect, while the nitrogen fertilization effect was positive. By contrast, water volume had positive effects on hue and chloride content, while the effects of nitrogen fertilization were negative.

\section{Relations between physical and chemical parameters}

From Figure 10 the following observations may be made:

- Price index was negatively associated with chloride content and hue, positively with burning capacity, nitrate and total alkaloid content, less with leaf area and specific leaf weight.

- Leaf area was positively and strongly associated with leaf dry weight (Leaf DW) and chromaticity parameters, negatively with specific leaf weight.

- Specific leaf weight was positively associated with leaf nitrate content and negatively with chromaticity parameters.

- Burning capacity was strongly associated with leaf chemical parameters: positively with alkaloid and nitrate content, and negatively with chloride content; the relation with specific leaf weight was weak.

- Total alkaloid content was positively, but weakly associated with chroma and leaf nitrate content, negatively with chloride content; a negative relation was also observed between chromaticity parameters and leaf nitrate content and, except for hue, with leaf chloride content.

\section{DISCUSSION}

In this study the yield of cured leaves increased as water and nitrogen availability increased, but at a decreasing rate. The total water volume used to obtain a high yield with satisfactory quality ranged from 3000 to $3500 \mathrm{~m}^{3}$ $\mathrm{ha}^{-1}$, less than that reported by RUGGIERO (56) in the Volturno plain and by PostigLIONE et al., (53) in the Sele plain, and similar to that reported by CAROTENUTO (10) in the Sarno plain and QUAGLIETTA et al., (54) in the Benevento area, but with untopped plants. However, the low response to nitrogen rates exceeding $160 \mathrm{~kg} \mathrm{ha}^{-1}$ may have been caused by the nature of the soil previously used for tobacco cultivation, which was already very fertile. The year influenced the yield: the warmer and wetter year (2002) was more productive, mainly in the plot irrigated with the lower volume and with hybrid R7-11, whereas in both years the cv TN86 showed a higher yield.

As regards yield quality, the data showed a decreasing price index with increasing water volumes, particularly in the unfertilized plot. This result contradicts the results reported by FRANKLIN et al., (21) who observed no water volume effect on yield or the price index, and also the findings of CAVLEK et al. (13), MAJERNIK (37), and MCKEE and STREET (39) who all observed yield and price 


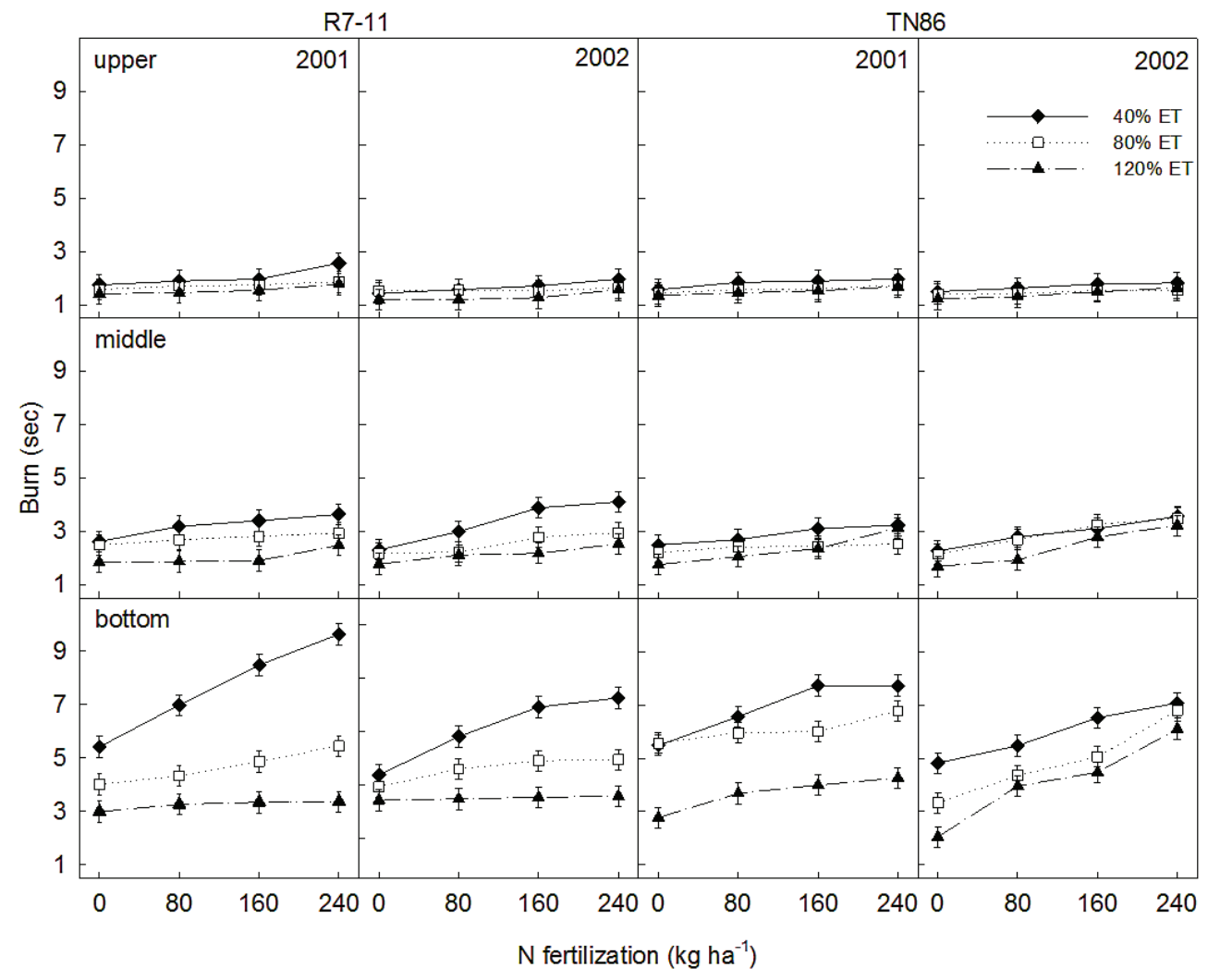

Figure 6. Influence of $\mathbf{N}$ fertilization, irrigation (\% ET), cultivar (R7-11, TN86), year and leaf stalk position on burning duration. Bars show $95 \%$ pointwise confidence intervals.

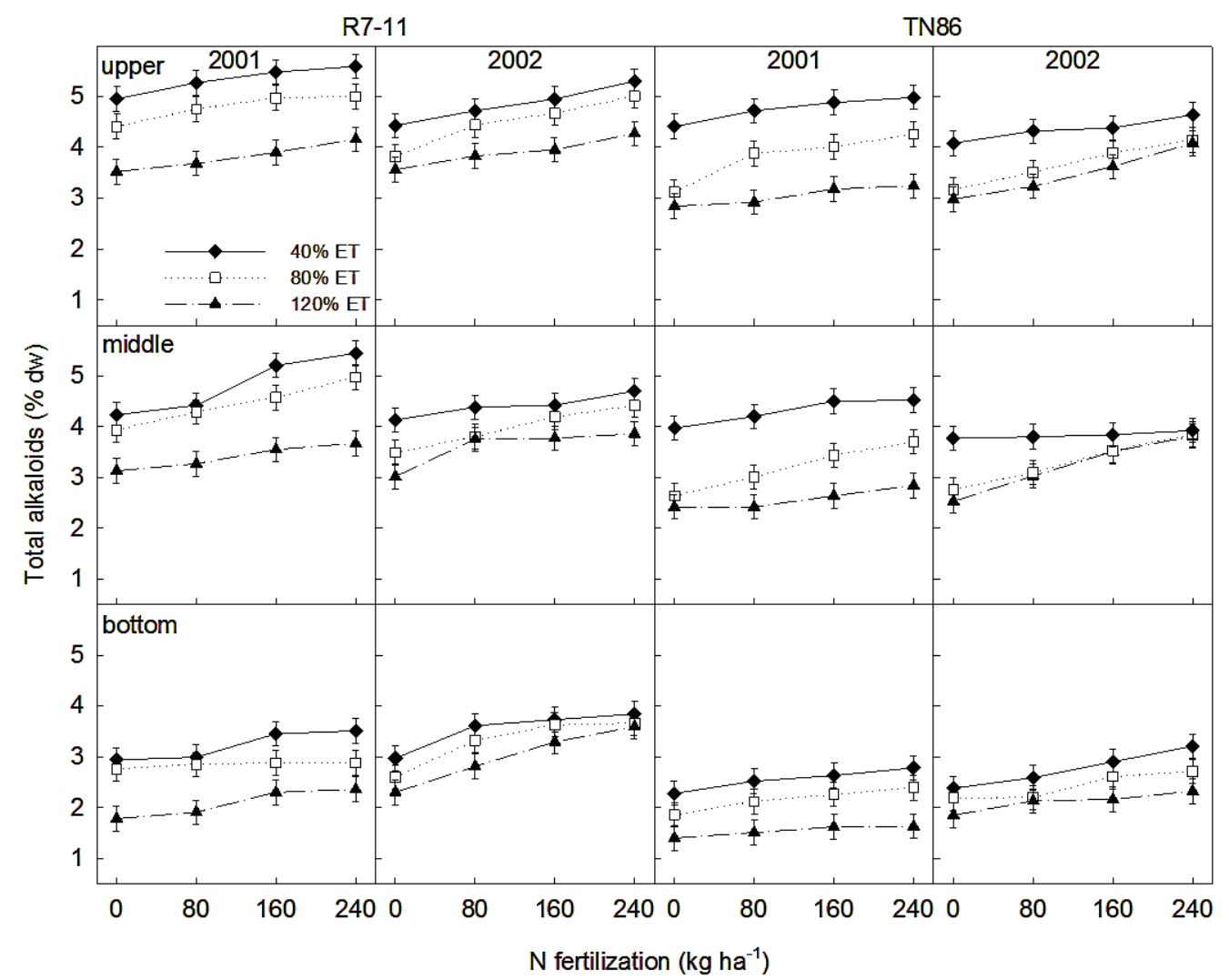

Figure 7. Influence of $\mathbf{N}$ fertilization, irrigation (\% ET), cultivar (R7-11, TN86), year and leaf stalk position on total alkaloids concentration. Bars show $95 \%$ pointwise confidence intervals. 


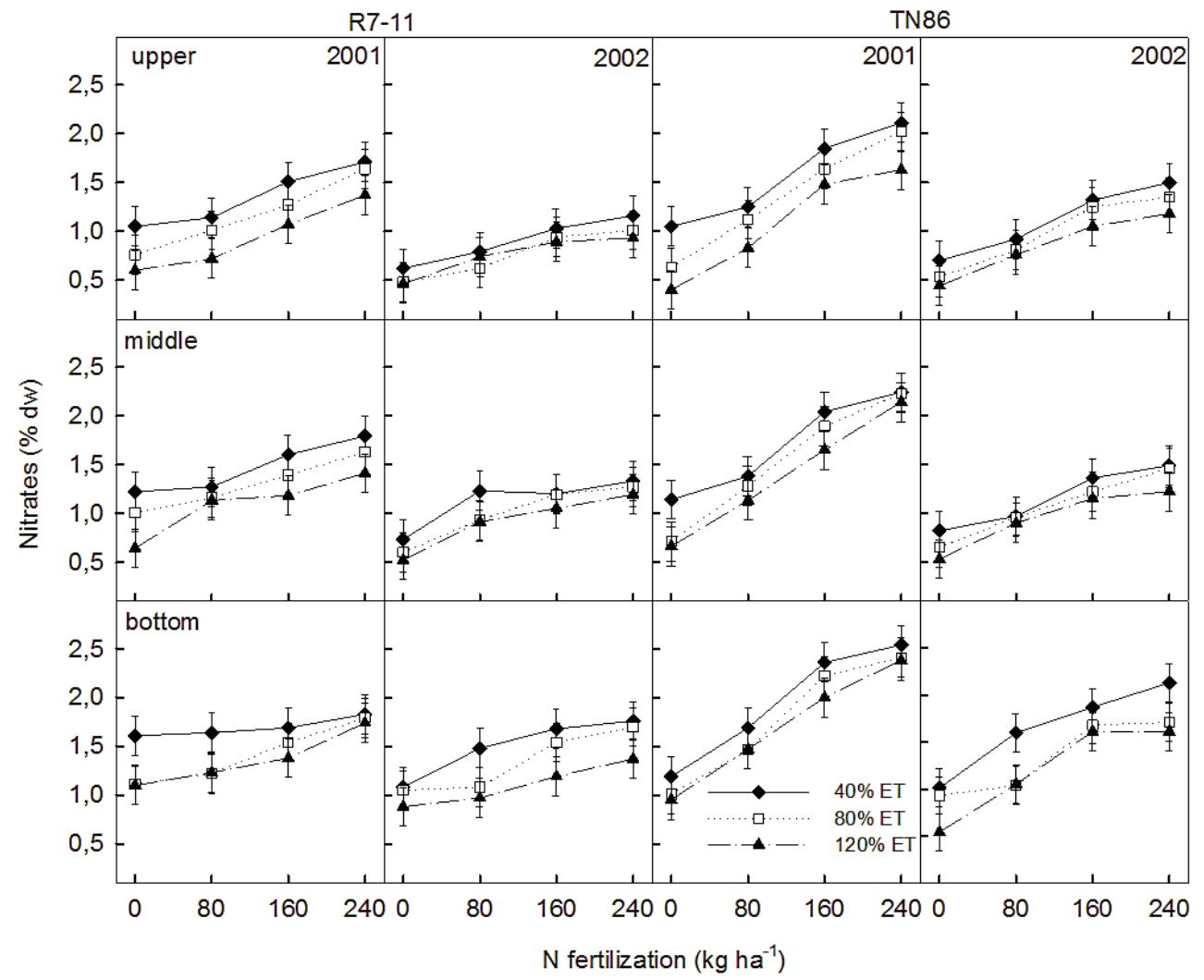

Figure 8. Influence of $\mathbf{N}$ fertilization, irrigation (\% ET), cultivar (R7-11, TN86), year and leaf stalk position on nitrate concentration. Bars show $95 \%$ pointwise confidence intervals.

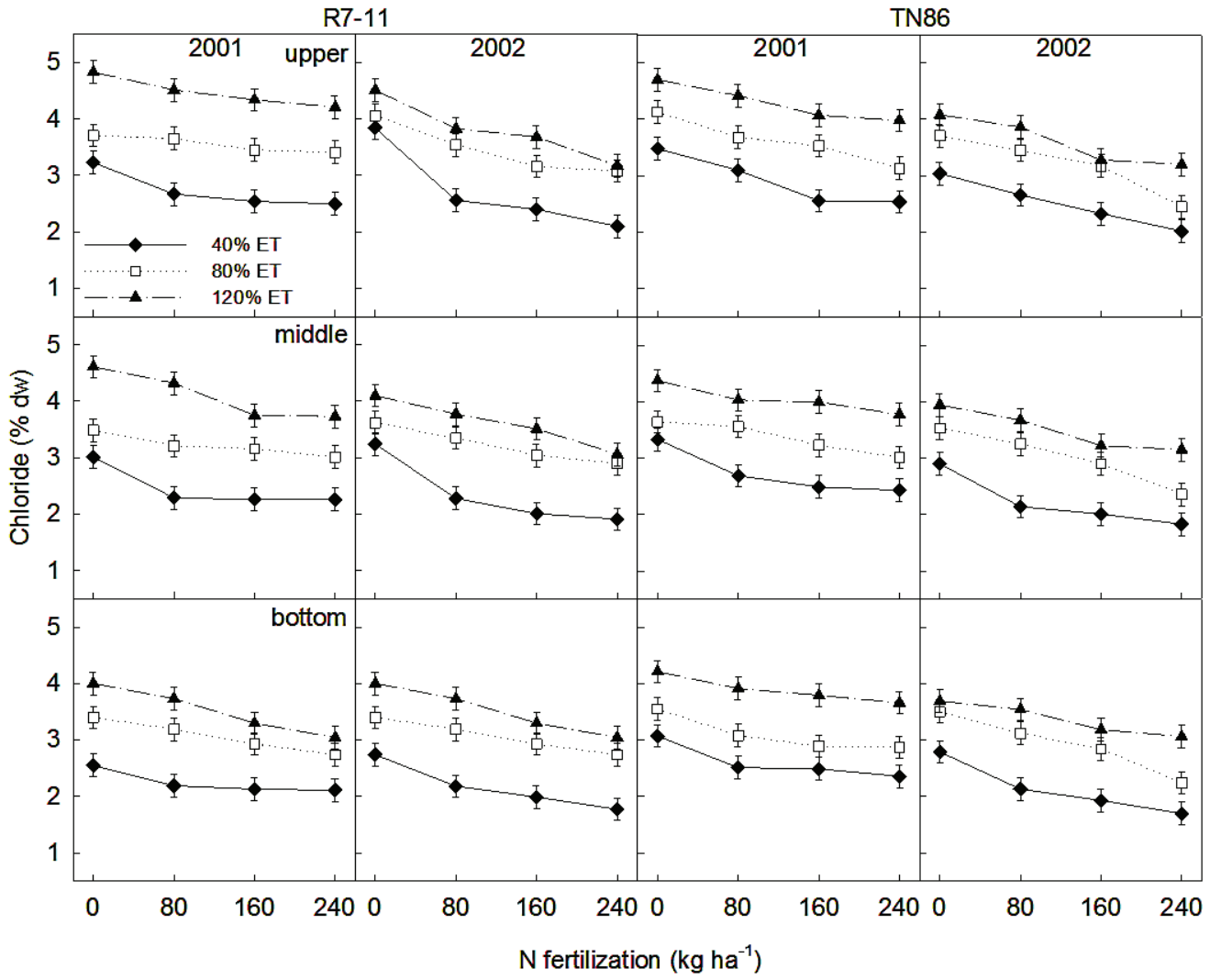

Figure 9. Influence of $\mathrm{N}$ fertilization, irrigation (\% ET), cultivar (R7-11, TN86), year and leaf stalk position on chloride concentration. Bars show $95 \%$ pointwise confidence intervals. 
index improvements as effects of increasing water volumes. As opposed to water volume, with a nitrogen fertilization increase up to $160 \mathrm{~kg} \mathrm{ha}^{-1}$ the price index increased. These results confirm those of CASTELLI et al. (12), EVANYLO and SiMS (19) and FRANKLIN et al. (21), while LINK and TERRILL (32) observed no differences between 110 and $225 \mathrm{~kg} \mathrm{ha}^{-1}$ and ATKINSON and SIMS (7) reported leaf quality to be lowered with either very low $\left(0-80 \mathrm{~kg} \mathrm{ha}^{-1}\right)$ or very high (300-400 kg ha $\left.{ }^{-1}\right)$ applications of $\mathrm{N}$ fertilizer. Given the different effects of $\mathrm{N}$ rate and water volume on yield and price index, the higher class A equivalent yield was achieved with $80 \%$ ET and $160 \mathrm{~kg} \mathrm{ha}^{-1}$ of $\mathrm{N}$, confirming the results of LINK and TERRILL (32), who found no differences in yield value between 170 and $225 \mathrm{~kg} \mathrm{ha}^{-1}$ of $\mathrm{N}$, and PELIVANOSKA et al. (52), who obtained their best results with $150 \mathrm{~kg} \mathrm{ha}^{-1}$ of $\mathrm{N}$ and with irrigation at $50-70 \%$ of field water capacity.

The multiple regression equation between yield parameters and the factors in question showed a sufficiently high coefficient of determination for yield $\left(\mathrm{R}^{2}=0.904\right)$ and for class A product $\left(\mathrm{R}^{2}=0.779\right)$, but not for price index for which the reported value $\left(\mathrm{R}^{2}=0.556\right)$ suggests the influence of factors differing from those tested. Moreover, the relation between the parameters showed that cured leaf area (LA) had a substantial positive effect upon unit yield $\left(\mathrm{R}^{2}=0.519\right)$. By contrast, the relation between leaf area and price index was rather weak $\left(\mathrm{R}^{2}=0.051\right)$.

All the studied factors positively affected leaf area, the main effect being the year, to a lesser extent water volume, $\mathrm{N}$ fertilization and genotype. Although a higher specific leaf weight was measured with increasing $\mathrm{N}$ fertilization, this effect changes in relation to year and decreases as the water volume increased. As with the findings for LA, the relation between specific leaf weight (SLW) and price index was weak $\left(\mathrm{R}^{2}=0.060\right)$, but when considered together had more influence $\left(\mathrm{R}^{2}=0.256\right)$.

To evaluate tobacco quality, not only LA and SLW are important but also color since it is a distinctive feature. Given that the chromaticity parameters are not independent of one another, the determination coefficient between price index and $\mathrm{L}^{*}, \mathrm{C}^{*}$ and $\mathrm{H}^{*}$ was not very strong $\left(\mathrm{R}^{2}=0.455\right)$, which may well be due to the weak and different response of each parameter to the agronomic factors under observation: the increase in water volume reduced $\mathrm{C}^{*}$ and increased $\mathrm{H}^{*}$, while $\mathrm{N}$ fertilization reduced $\mathrm{H}^{*}$, but water volume and $\mathrm{N}$ fertilization did not affect the $\mathrm{L}^{*}$ parameters. In this research the relation between price index and leaf area, specific leaf weight and chromaticity parameters was $\mathrm{R}^{2}=0.518$.

Decreasing chroma and increasing hue as water volume rose is likely to be caused also by the chloride content of the water used $\left(116 \mathrm{mg} \mathrm{L}^{-1}\right)$ : as the water volume increased, so did the leaf chloride content, with negative effects on the price index. This is in agreement with the results reported by KitAMURA et al. (27), Miner (41), and Sims and MulCHI (42) who observed a pale ink color or gray with a bad smell when the chloride content in plants was high. However, ISHIZAKI and AKIYA (30) reported no differences in color and physical properties for leaves with different chloride contents up to 5\%. Also EVANYLO and Sims (19) failed to observe differences in price index with the changing chloride content in the leaves. However, CHEN (15) found a
Table 2. Multiple regression equations and $\mathbf{R}^{2}$ coefficients describing the relationships between examined parameters of air-cured tobacco leaves and experimental factors.

\begin{tabular}{lll}
\hline Parameters & \multicolumn{1}{c}{ Regression equation } & $R^{2}$ \\
\hline Yield & $1.75+0.44 y+0.37 w+0.64 \mathrm{~N}+0.42 \mathrm{~g}$ & 0.90 \\
Price index & $53.77-0.44 \mathrm{w}+0.59 \mathrm{~N}+0.17 \mathrm{~g}$ & 0.55 \\
Eq. yield & $0.96+0.29 \mathrm{y}+0.75 \mathrm{~N}+0.38 \mathrm{~g}$ & 0.77 \\
LA & $194.43+0.60 \mathrm{y}+0.23 \mathrm{w}+0.33 \mathrm{~N}+0.29 \mathrm{~g}$ & 0.59 \\
D.W.leaf & $2.17+0.37 \mathrm{y}+0.22 \mathrm{w}+0.49 \mathrm{~N}+0.43 \mathrm{~g}$ & 0.59 \\
SLW & $7.30-0.85 \mathrm{y}-0.12 \mathrm{w}+0.31 \mathrm{~N}+0.16 \mathrm{~g}$ & 0.85 \\
Burn & $3.36-0.14 \mathrm{y}-0.73 \mathrm{w}+0.54 \mathrm{~N}$ & 0.84 \\
Brightness & $37.15+0.77 \mathrm{y}+0.20 \mathrm{~g}$ & 0.62 \\
Chroma & $24.20+0.75 \mathrm{y}-0.24 \mathrm{w}-0.11 \mathrm{~g}$ & 0.63 \\
Hue & $66.22+0.65 \mathrm{y}+0.15 \mathrm{w}-0.28 \mathrm{~N}-0.18 \mathrm{~g}$ & 0.54 \\
Alkaloids & $5.18-0.65 \mathrm{w}+0.42 \mathrm{~N}-0.52 \mathrm{~g}$ & 0.86 \\
Nitrates & $1.09-0.41 \mathrm{y}-0.23 \mathrm{w}+0.73 \mathrm{~N}+0.16 \mathrm{~g}$ & 0.77 \\
Chloride & $3.13-0.23 \mathrm{y}+0.78 w-0.47 \mathrm{~N}$ & 0.87 \\
\hline
\end{tabular}

$\mathrm{y}=$ year; $\mathrm{w}=$ water volume; $\mathrm{N}=\mathrm{N}$-rate; $\mathrm{g}$ = genotype

low tobacco quality with water chloride content higher than $0.6 \mathrm{mg} \mathrm{L}^{-1}$.

From the literature, there is conflicting evidence on the effects of water volume and $\mathrm{N}$ fertilization on the burning capacity of cured leaves. KITANOSONO (28), ORPHANOS and METOCHIS (49) reported an improvement in this parameter with irrigation, while MCKEE and STREET (39) observed no effect for Maryland tobacco. CASTELLI et al. (12) and MylonAs et al. (45) reported a decrease in burning capacity with increasing nitrogen fertilization, while INTERLANDI et al. (29) did not observe any difference on increasing $\mathrm{N}$ fertilization from 100 to 300 $\mathrm{kg} \mathrm{ha}^{-1}$. In this research variations in the burning capacity of the cured leaf (as an effect of water volume and $\mathrm{N}$ fertilization) concerned mostly the bottom leaves, to a lesser extent the middle and least of all the top leaves. This is probably due to leaf chloride content, which increased from bottom to top, and from plant topping and to topping-mid harvest, which governs leaf growth and ripening at harvest, leaf dry weight and the concentration of chemical components. Burning capacity was closely correlated with leaf physical and chemical parameters $\left(R^{2}=0.847\right)$, showing the positive effect of specific leaf weight, brightness, total alkaloid and nitrate content, and negative effect of chroma and chloride; the effect of the remaining parameters had little influence. According to ORPHANOS and METOCHIS (49) and ZEHLER et al. (63), chloride content in the cured leaves higher than $3 \%$ or $2 \%$ is considered the upper limit for good burning capacity. The data reported in this research show that, with the exception of the bottom leaves, the $3 \%$ content was widely exceeded, which may well explain the low burning capacity. This effect has been widely ascribed to the increase in leaf hygroscopic coefficients with the rise in chloride content $(19,27,30,38,41,42)$.

FUQUA et al. (22, 23), MCCANTS and Woltz (38) reported a reduction of chloride uptake as soil nitrate content increased. Our data support this inverse trend, albeit in disagreement with ORPHANOS and METOCHIS (50) who found no leaf chloride content decrease with the 


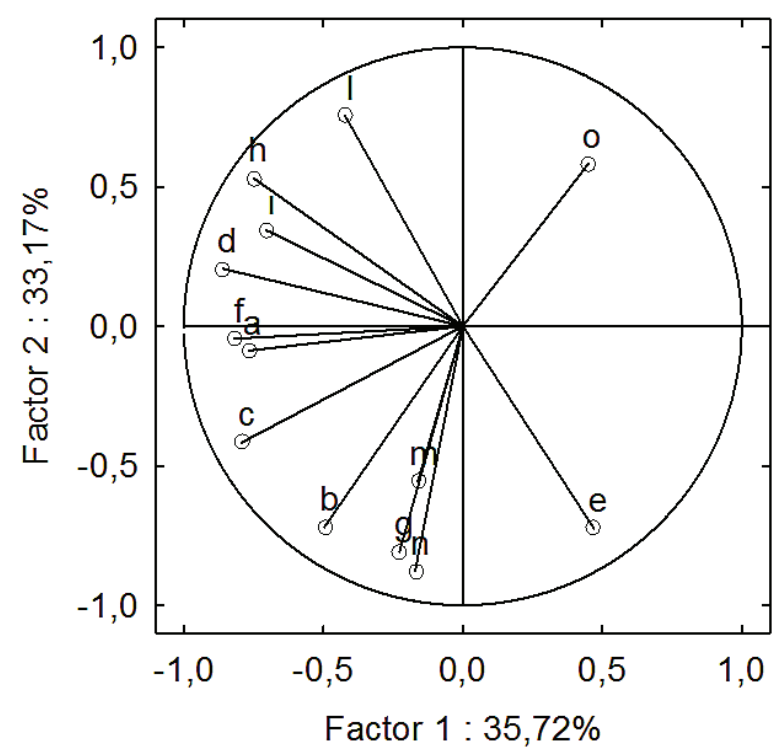

Figure 10. Projection of relationships between yield, physical and chemical parameters of cured leaves on the factor-plane $(1 \times 2)$. a = yield; $b=$ price index; $c=$ eq. yield; $d=$ leaf area; $e=$ specific leaf weight; $f=$ dry weight leaf; $g=$ burn duration; $\mathrm{h}=$ brightness; $\mathrm{i}=$ chroma; $\mathrm{I}=$ hue; $\mathrm{m}=$ alkaloids; $\mathrm{n}=$ nitrates; $\mathrm{o}=$ chlorides .

increase in nitrogen fertilization.

As regards the effects on total alkaloid and nitrate content of the leaves, our data confirm the related findings of ANDERSEN et al. (1), EVANYLO and Sims (19), MACKOWN et al. (35), MULCHi et al. (43), Postiglione et al. (53), WILLIAMSON and CHAPLIN (62). It should also be pointed out that water volume and genotype had more influence on total alkaloid content, $\mathrm{N}$ fertilization and year were more related with nitrate content, and leaf stalk position with both parameters.

A positive correlation was found between total alkaloid content and price index, which is partly in agreement with EVANYLO and SIMS (19) and MiNER and SiMS (41), who observed a high total alkaloid content for high yield and high quality. At the same time, a negative correlation was observed between total alkaloid and chloride content and between chloride and nitrate content. This is at odds with KitAMURA et al. (27) and MUlCHI (42) who recorded increasing total alkaloid content, or observed no variations with the increasing rate of chloride applied.

\section{CONCLUSIONS}

Our findings suggest that in Campania, with this cropping technique, a total water volume between $3000-3500 \mathrm{~m}^{3} \mathrm{ha}^{-1}$ and with $160 \mathrm{~kg} \mathrm{ha}^{-1}$ of $\mathrm{N}$ fertilization is enough to achieve a good-quality high yield. In these conditions there are no reasons for irrigating with water volumes higher than $80 \%$ ET. However, with $40 \%$ ET water volume can produce a yield with a lower commercial value than $80 \%$ ET, but not such as to be considered inadequate. In the agronomic conditions in which we operated, there were limited margins for increase in yield due to $\mathrm{N}$ fertilization. Hence the administration of rates higher than $160 \mathrm{~kg} \mathrm{ha}^{-1}$ is not only unprofitable but also harmful for the environment, given that the quantity not taken up by plants undergoes nitrification due to soil microorganisms and is then leached, with negative repercussions on groundwater quality.

In terms of quality traits of cured leaves, water volume and nitrogen fertilization have the opposite effects: price index, specific leaf weight, burning capacity, total alkaloid and nitrate content increased with $\mathrm{N}$ fertilization and decreased with increasing water volume, while hue and chloride content increased with the water volume and decreased with an increase in the nitrogen fertilization rate. Both water volume and nitrogen fertilization had little influence on leaf color.

The year was an important factor, influencing yield, leaf area, specific leaf weight and leaf color. The genotype influenced many of the parameters under observation, especially in the first year, which was drier and not as cool as the second. TN86 showed more stability both for yield and for quality traits.

Leaf area, specific leaf weight and chromaticity influenced the price index only when acting in concert. Burning capacity was associated positively with total alkaloid and nitrate content, negatively with leaf chloride content. The total alkaloid content was positively but weakly associated with nitrate content, and strongly, but negatively, with leaf chloride content. The relationship between leaf nitrate content and chloride was negative.

In brief, the findings of this research indicate that the tested factors chiefly work in interaction and often have contrasting effects upon yield and, to a greater extent, upon cured tobacco quality. At the same time, it should be noted that several quality indexes are also subordinate to irrigation water quality, especially chloride content. This should be duly taken into account in future research.

\section{ACKNOWLEDGMENTS}

Our research was supported by the Italian Council for Research and Experimentation in Agriculture (CRA).

\section{REFERENCES}

1. Andersen, R.A., M.J. Kasperbauer, and H.R. Burton: Shade during growth-effects on chemical composition and leaf color of air-cured Burley tobacco; Agron. J. 77 (1985) 543-546.

2. Angelino, G., S. Ascione, and C. Ruggiero: Effect of water and nitrogen supply on leaf growth and anatomy of Burley tobacco; Agr. Med.134 (2004) 185-192.

3. Anonymous: 1998-1999 Lime and fertilizer recommendations; Ky. Agric. Exp. Stn. Bull. AGR-1 (1998).

4. Ascione, S., P. Lombardi, and C. Ruggiero: Influenza della diversificazione colturale e della concimazione fosfo-azotata sulla produzione del tabacco Burley e mais (Influence of crop system and N-P fertilization on yield of Burley tobacco and maize); Riv. Agron. 34 (2000) 81-91.

5. Ascione, S. and M. Niglio: Missing data estimation in 
precipitation time series. Giornata di Studio: Metodi Statistici e Matematici per l'Analisi delle serie idrologiche; Rome (2003) 259-270, CNR-GNDCI, no. 2812.

6. Atkinson, W.O., J.L. Ragland, J.L. Sims, and B.J. Bloomfield: Nitrogen composition of Burley tobacco. I. The influence of irrigation on the response of Burley tobacco to nitrogen fertilization; Tob. Sci. 13 (1969) 123-126.

7. Atkinson, W.O. and J.L. Sims: Nitrogen composition of Burley tobacco. II. Influence of nitrogen fertilization, suckering practice, and harvest date on yield, value, and distribution of dry matter among plant parts; Tob. Sci. 15 (1971) 63-66.

8. Atkinson, W.O., J.L. Sims, and J.R. Calvert: Response of reduced alkaloid Burley genotypes to nitrogen fertilization; Tob. Sci. 20 (1976) 32-34.

9. Bridges, T.C., L.R. Walton, and J.H. Casada: Assessing the quality of Burley tobacco. Part.1: grade index and associated factors; Tob. Sci. 38 (1994): 38-41.

10. Carotenuto, R.: Le esigenze idriche del tabacco (Tobacco water necessity); Ann. Ist. Spe. Tabacco VIII (1981) 101-107.

11. Carotenuto, R., R. Troncone, and P. Martiniello: Chromaticity parameters in relation to visual grades of the flue-cured tobacco; Agron. J. 82 (1990) 460-462.

12. Castelli, F., F. Miceli, and F. Piro: Effetti delle modalità di raccolta e cura in tabacco (Nicotiana tabacum L.) Burley a differente fertilizzazione azotata e densità di popolamento (Effects of three harvest-curing methods at different levels of nitrogen and plant in Burley tobacco (Nicotiana tabacum L.); Riv. Agron. 24 (1990) 308-316.

13. Cavlek, M., I. Tursic, and M. Berdin: Irrigation of flue-cured tobacco consistent with moisture levels; CORESTA Meet. Agro-Phyto Groups (1993) Budapest.

14. Cavlek, M., I. Tursic, and T. Cosic: The dependence of yield and quality of tobacco on irrigation in the conditions of north-west Croatia; Tutun 47-1/6 (1997) 39-44. Bulletin CORESTA (1999) 1, 2397.

15. Chen, H.J.: Influence of copper and chlorine contents of irrigation water on tobacco; Bull. Taiwan Tob. Res. Inst. 8 (1978) 57-65. Tob. Abstracts 1 (1980) 73, n.197.

16. Clough, P.F. and F.L. Milthorpe: Effects of water deficit on leaf development in tobacco; Aust. J. Plant Physiol. 2 (1975) 291-300.

17. Cuocolo, L., G. Caruso, and L. Postiglione: Effetti della cultivar, della concimazione azotata e dell'epoca di raccolta sulla produzione del tabacco Burley di tipo americano (Effect of cultivar, nitrogen fertilization, and harvest date on stalk-cut Burley tobacco); Il Tabacco 1 (1993) 18-23.

18. Doorembos, J. and W.O. Pruitt: Crop water requirements; FAO Irrigation and Drainage 24 (1977) Rome.

19. Evanylo, G.K. and J.L. Sims: Nitrogen and potassium fertilization effects on yield and quality of Burley tobacco; Soil Sci. Soc. Am. J. 51 (1987) 1536-1540.

20. Evanylo, G.K., J.L. Sims, and J.H. Grove: Nutrient norms for cured Burley tobacco; Agron. J. 80 (1988) 610-614.

21. Franklin, R.E., R.W. Teater, R.B. Curry, and G.O. Schwab: Nitrogen-irrigation interactions in Burley tobacco production; Agron. J. 56 (1964) 361-362.

22. Fuqua, B.D., J.E. Leggett, and J.L. Sims: Accumulation of nitrate and chloride by Burley tobacco; Can. J. Plant Sci. 54 (1974) 167-174.

23. Fuqua, B.D., J.L. Sims, J.E. Leggett, J.F. Benner, and W.O. Atkinson: Nitrate and chloride fertilization effects on yield and chemical composition of Burley tobacco leaves and smoke; Can. J. Plant Sci. 56 (1976) 893-899.

24. Hsiao, T. C.: Plant responses to water stress; Ann. Rev. Plant Physiol. 24 (1973) 519-570.

25. Hsiao, T.C. and L.K. Xu: Sensitivity of growth of roots versus leaves to water stress: biophysical analysis and relation to water transport; J. Exp. Bot. 51 (2000) 1595-1616.

26. King, M.J.: Bilateral leaf expansion of tobacco under water stress; Can. J. Plant Sci. 68, 3 (1988) 887-92.

27. Kitamura, T., T. Ito, H. Kudo, and K. Ohzeki: Studies on the absorption of chloride by Burley tobacco. I. Effects of chloride content in the cured leaves on the chemical and physical properties and smoking quality of tobacco; Morioka, Jpn. Tob. Exp. Stn. Bull. 13 (1978) 1-12. Tob. Abstr. 6 (1979) 491-492

28. Kitanosono, H.: Studies on the causes of burning of tobacco in paddy fields. 1. Effects of soil moisture, light intensity and quantity of fertilizers on burning of tobacco leaves; Field Crop Abstr. 31 (1976) 3829.

29. Interlandi, G., M.G. Tremola, R. Carotenuto, F. Piro, V. Leone, and R. Cutolo: Crop value response of Burley tobacco to $\mathrm{N}$ application timing and rate; Tobacco 9 (2001) 51-55.

30. Ishizaki, H. and T. Akiya: Effect of chlorine on growth and quality of tobacco. I. Relation between chlorine amount given at sowing and quality of the harvested leaves; Utsunomiya Tab. Shikenjo Hokoku 16 (1978) 55-62. Tob. Abstr. 2 (1981) 147.

31. Ligon, J.T. and G.R. Benoit: Morphological effects of moisture stress on Burley tobacco; Agron. J. 58 (1966) 35-38.

32. Link, L.A. and T.R. Terrill: The influence of nitrogen and potassium fertilization on the yield, quality, and chemical composition of Burley tobacco; Tob. Sci. XXVI (1982) 81-84.

33. Littlemore, J., P.E. Tonello, and T.S. Rasmussen: Nine years continuous tobacco monocropping compared with alternative cropping frequencies and sequences. Part 1. Effect on leaf yield and quality; Tob. Sci. 35 (1991) 79-84.

34. Lourenco, M.G., J.E.M. Ferrao, E.T.L. Figueiredo, J.A.T. Amaro, and M.E.V. Rocha: Effects of rates and forms of nitrate fertilizer on Burley tobacco in Portugal; Bull. Spéc. CORESTA, Congress Harare, (1994) 37, A 28.

35. MacKown, C.T., S.J. Crafts-Brandner, and T.G. Sutton: Relationships among soil nitrate, leaf nitrate, and leaf yield of Burley tobacco: effects of nitrogen management; Agron. J. 91 (1999) 613-621.

36. MacKown, C.T. and T.G. Sutton: Recovery of fertilizer nitrogen applied to Burley tobacco; Agron. J. 89, 2 (1997) 183-189.

37. Majernik, F.: Irrigation of Virginia tobacco; Bull. Tabak. Priem. 23 (1980) 33-40. 
38. McCants, C.B. and W.G. Woltz: Growth and mineral nutrition of tobacco; Adv. Agron. 19 (1967) 211-265.

39. McKee, C.G. and O.E. Street: Irrigation studies with Maryland tobacco; Md. Agric. Exp. Stn. misc. Bull. 931 (1978) $26 \mathrm{p}$.

40. Milyanchev, I.: Crop rotation an important factor for efficient soil utilization (in tobacco production); Bul. Tjutjun, 34-5 (1989) p. 20-3.

41. Miner, G. S. and J.L. Sims: Changing fertilization practices and utilization of added plant nutrients for efficient production of tobacco; Recent. Adv. Tob. Sci. 9 (1983) 4-76.

42. Mulchi, C.L.: Chloride effects on agronomic, chemical and physical properties of Maryland tobacco. I. Response to chloride applied to the soil; Tob. Sci. XXVI (1982) 113-116.

43. Mulchi, C.L., C.G. McKee, W.J. Moyer, and O.S. Street: The relationships of estimated yields and chemical contents of Maryland tobacco and seasonal rainfall; Tob. Sci. 31(1987) 8-12.

44. Munthali, F.C.: Response of Burley tobacco varieties to varying rates of nitrogen fertilizers; Bull. Spéc. CORESTA, Congress Harare, (1994) p. 76, APOST 17.

45. Mylonas, V.A., V.N. Athanasiadis, and X.A. Perakis: Effects of nitrogen and potassium on yield, value and chemical composition of Burley tobacco; Coop. Cent. Sci. Res. Relat. Tob. Phytopathol. Stud. Group Agron. Stud. Group Rep. (1979) 70-83.

46. Nelson, R.A.: Methods of analysis for tobacco and tobacco products; U.S. Treasury Depart. Int. Rev. Serv. 445 (1960) 10-60.

47. Nonami, H. and J.S. Boyer: Wall extensibility and cell hydraulic conductivity decrease in enlarging stem tissues at low water potentials; Plant Physiol. 93 (1990) 1610-1619.

48. Nonami, H. and J.S. Boyer: Decreased growth-induced water potential: a primary cause of growth inhibition at low water potential; Plant Physiol. 114 (1997) 501-509.

49. Orphanos, P.I. and C. Metochis: Yield and quality of tobacco grown with supplementary irrigation; Agron. J. 77 (1985) 689-695.

50. Orphanos, P.I. and C. Metochis: Nitrogen fertigation of flue-cured tobacco in a Mediterranean environment; Plant and Soil 125 (1990) 29-37

51. Pelivanoska, V. and J. Trajkoski: The irrigation and mineral nutrition effect on the anatomic structure and some physical characteristics of tobacco type Burley; Tutun 49, 7-12 (1999) 101-110.

52. Pelivanoska, V., J. Trajkoski, and J.K. Filiposki: Effects of fertilization and irrigation on yield and quality of tobacco type Burley; Bull. Spec. CORESTA, Congress Lisbon, (2000) 109, APOST 8.

53. Postiglione, L., G. Barbieri, and E. De Falco: Risultati produttivi e qualitativi del tabacco "Burley" sottoposto a carenze o eccessi di acqua in diversi periodi del ciclo biologico (Yield and quality of "Burley" tobacco under water deficit or water excess during different phases of biological cycle); Irrigation and drainage 36 (1989) 115-20.

54. Quaglietta Chiarandà, F., R. D'Andria, and G. Morelli: Influenza di volumi irrigui crescenti sulla quantità $\mathrm{e}$ sullaqualità delle rese di tre varietà di tabacco ( Nicotiana tabacum L.) (Effect of increasing irrigation volumes on the quantity and quality of yield rates of three tobacco varieties); Irrigation and drainage 2 (1988) 25-31.

55. Quaglietta Chiarandà, F., P. Tedeschi, and G. Zerbi: Effect of soil water stress on leaf growth of Burley tobacco; Irrigazione 4 (1982) 29-33.

56. Ruggiero, C.: Irrigazione del tobacco. Influenza del volume stagionale sulla resa nella piana del Volturno (Tobacco irrigation. Influence of seasonal water volumes on the yield in the Volturno plain); L'Italia agricola 10 (1978) 121-128.

57. Sims, J.L., S.J. Sheen, C. Grunwald, and W.O. Atkinson: Effects of nitrogen fertilization and stalk position on certain chemical and physical characteristics of thee tobacco genotypes; Can. J. Plant Sci. 55 (1975) 485-490.

58. Srivastava, R.P., and D. Subbarao: A note on the effect of different crop rotations on quality of cigar wrapper tobacco (Nicotiana tabacum L.); Tob. Res. 9, 2 (1983) 95-98.

59. Subramaniam, T.S.: Signalling method of irrigation; CORESTA Meet. Agro-Phyto Groups, Suzhou, (1999) AP57.

60. Tripathi, S.N., K.D. Singh, and A.K. Pandey: Influence of irrigation, nitrogen level and time of its application on leaf yield, physical quality parameters and economics of chewing tobacco; CORESTA, Bull. Tob. Symp. 20 (1998) A7.

61. Tumbaga, A.L. and O.B. Zamora: Growth and quality of flue-cured tobacco (Nicotiana tabacum L.) at four methods of planting and leaves of irrigation; J. of Tob. Sci. and Technology 1, 2 (1986) 202-208.

62. Williamson, R.E. and J.F. Chaplin: Levels of chemical constituents in cured leaves of four Burley tobacco cultivars according to stalk position; Tob. Sci. XXV (1981) 75-78.

63. Zehler, E., H. Kreipe, and P.A. Gething: Tobacco (Nicotiana tabacum); (1981) 63-64. IPI Res. Topics 9. International Potash Institute, Bern, Switzerland.

\section{Corresponding author:}

Celestino Ruggiero

Department of Agricultural Engineering and Agronomy University of Naples Federico II

80055 Portici (NA), Italy

E-mail:cruggier@unina.it 